\title{
06.01.00 АГРОНОММИЯ
}

\section{АГРОКЛИМАТИЧЕСКАЯ ХАРАКТЕРИСТИКА РЕГИОНОВ НЕЧЕРНОЗЕМНОЙ ЗОНЫ РОССИЙСКОЙ ФЕДЕРАЦИИ И ОЦЕНКА ПРИГОДНОСТИ ДЛЯ ВОЗДЕЛЫВАНИЯ СОВРЕМЕННЫХ РАННЕСПЕЛЫХ СОРТОВ СОИ}

\author{
Дорохов Алексей Семенович, член-корреспондент РАН, доктор технических наук \\ Белышкина Марина Евгеньевна, кандидат сельскохозяйственных наук, старший научный со- \\ трудник лаборатории прогнозирования развития систем машин и технологий в АПК \\ ФГБНУ «Федеральный научный агроинженерный центр ВИМ» \\ 109428, г. Москва, 1-й Институтский проезд, д. 5, \\ тел.: (903) 271-31-05 \\ e-mail: vimsoya@yandex.ru
}

Ключевые слова: соя, Центральное Нечерноземье, агроэкологические районы, потепление климата, сумма активных температур, гидротермический коэффициент, северная граница соесеяния.

В последние годы в Центральном Нечерноземье фиксируется увеличение продолжительности теплого периода, которое происходит за счет возрастания числа дней с положительными температурами: переход через $0^{\circ} \mathrm{C}$ в сторону повышения температур наступает раньше, а в сторону понижения - позже принятых среднемноголетних значений. Целью исследований было проанализировать параметры изменения климата в Центральном Нечерноземье и обозначить смещение северной границы допустимого размещения посевов сои в регионе. В результате изучения массива агрометеорологических данных за 40-летний период - с 1981 по 2020 г2. - Центральный экономический регион Нечерноземной зоны РФ (ЦРНЗ РФ) был условно разделен на 3 агроэкологических района: северный (САР), чентральный (ЦАР) и южный (ЮАР). В основу разделения были заложены температурные климатические факторы - средняя температура за вегетационный период и сумма активных температур за вегетацию. Наряду с температурами были проанализированы суммы осадков и значение ГТК за вегетацию. Изменения агроклиматических условий в агроэкологических районах ЦРНЗ РФ в настоящее время существенно различаются: в северном агроэкологическом районе (Тверская, Ярославская, Костромская области) сумма температур составляет 2000-2200ㄷ, ГТК - 1,4-1,7, сумма осадков - 285-295. В центральном агроэкологическом районе (Смоленская, Московская, Калужская, Владимирская, Ивановская области) сумма температур составляет 2200-2400 드, ГТК - 1,1-1,4, сумма осадков - 265-285. В южном агроэкологическом районе (Брянская, Орловская, Рязанская, Тульская области) сумма температур составляет $2400-2600^{\circ} \mathrm{C}$, ГТК - 0,7-1,1, сумма осадков - 255-265. В целом, локальное изменение климата ЦРнз РФ привело к смещению изотермы суммы активных температур на 150-200 км в сторону высоких широт. Раннеспелые сорта сои способны формировать стабильную урожайность в изменившихся погодных условиях ЦРНЗ РФ. Биологические минимумы температур выдерживаются на всех этапах роста и развития, созревание наступает в августе - начале сентября.

\section{Введение}

По данным Росгидромета [1], за последние полвека наблюдается тенденция к повышению средней температуры воздуха. При этом скорость потепления в среднем по России значительно превосходит среднюю по земному шару и за период с 1976 по 2020 гг. составляет в среднем $0,51^{\circ} \mathrm{C}$ за десятилетие $[2,3,4,5,6]$.

Происходящие климатические изменения будут в дальнейшем способствовать расширению ассортимента раннеспелых сортов сои, в том числе и индетерминантного типа роста, для 


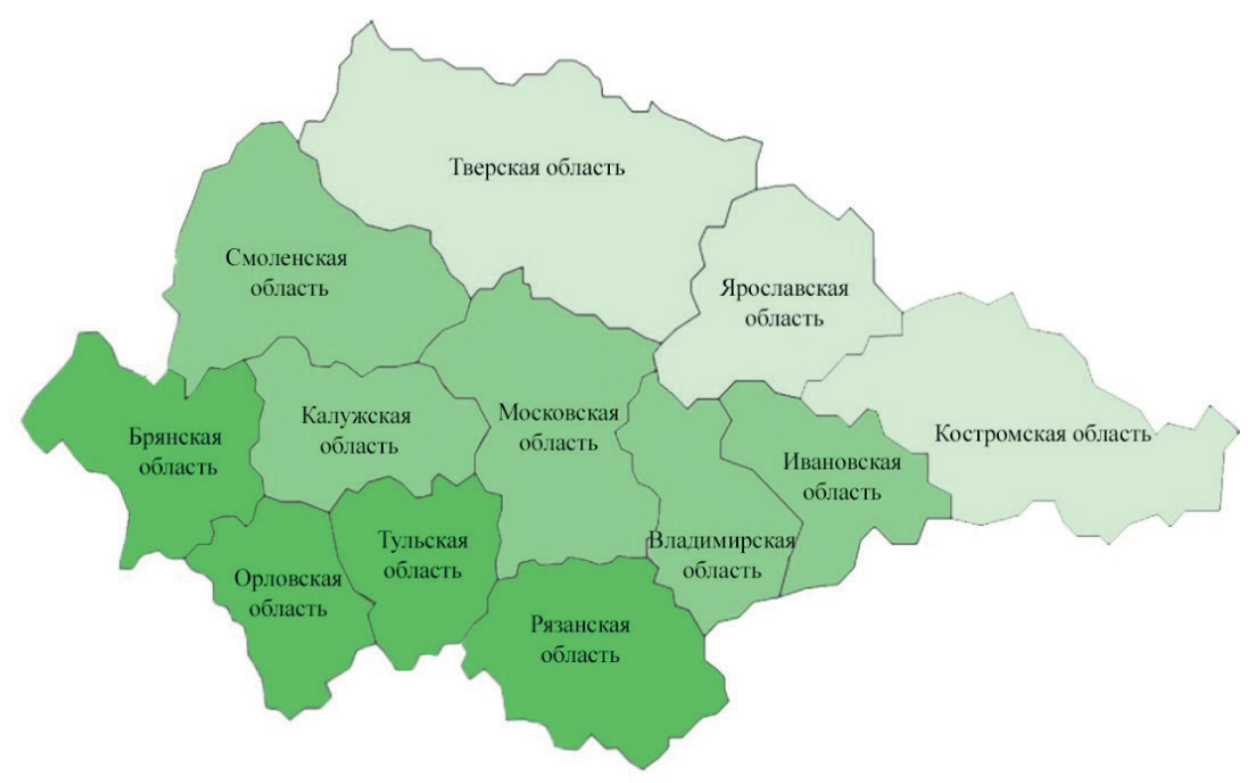

Рис. 1 - Агроэкологические районы Центрального региона Нечерноземной зоны Российской Федерации

возделывания в Центральном Нечерноземье, обеспечивающих максимальное использование агроклиматического потенциала региона, обусловленного локальным изменением климата $[7,8,9]$.

Цель исследований: проанализировать параметры изменения климата в Центральном Нечерноземье и обозначить смещение северной границы допустимого размещения посевов сои в регионе.

\section{Материалы и методы исследований}

В результате изучения массива данных Всероссийского научно-исследовательского института гидрометеорологической информации (ВНИИГМИ) [10] среднемесячных температур и осадков, сумм активных температур и ГТК с 1981 по 2020 гг., Центральный экономический реги- он Нечерноземной зоны для удобства анализа и в соответствии с поставленными задачами автором был условно разделен на 3 агроэкологических района: северный (САР), центральный (ЦАР) и южный (ЮАР). В основу разделения были заложены температурные климатические факторы - средняя температура за вегетационный период и сумма активных температур за вегетацию. Наряду с температурами, были проанализированы суммы осадков и значение ГТК за вегетацию.

\section{Результаты исследований}

К северному агроэкологическому району были отнесены Тверская, Ярославская и Костромская области (рис. 1, табл. 1). Средняя температура воздуха в течение вегетационного периода здесь составляет 15,0-16,0² , сумма ак-

Таблица 1

Характеристика агроэкологических районов Центрального региона Нечерноземной зоны Российской Федерации

\begin{tabular}{|l|c|c|c|c|c|}
\hline Агроэкологический район & Обозначение & $\begin{array}{c}\text { Средняя темпе- } \\
\text { ратура за май- } \\
\text { август, }{ }^{\circ} \mathrm{C}\end{array}$ & $\sum \mathrm{T} \geq 10^{\circ} \mathrm{C}$ & 乏 осадков, мм & $\begin{array}{c}\text { ГТК за вегетаци- } \\
\text { онный период }\end{array}$ \\
\hline $\begin{array}{l}\text { Северный } \\
\text { (Тверская, Ярославская, } \\
\text { Костромская области) }\end{array}$ & $16,0-18,0$ & $2000-2200$ & $285-295$ & $1,4-1,7$ \\
\hline $\begin{array}{l}\text { Центральный (Смоленская, } \\
\text { Московская, Калужская, } \\
\text { Владимирская, Ивановская } \\
\text { области) }\end{array}$ & $18,0-19,0$ & $2200-2400$ & $265-285$ & $1,1-1,4$ \\
\hline $\begin{array}{l}\text { Южный } \\
\text { (Брянская, Орловская, Ря- } \\
\text { занская, Тульская области) }\end{array}$ & $19,0-21,0$ & $2400-2600$ & $255-265$ & $0,7-1,1$ \\
\hline
\end{tabular}



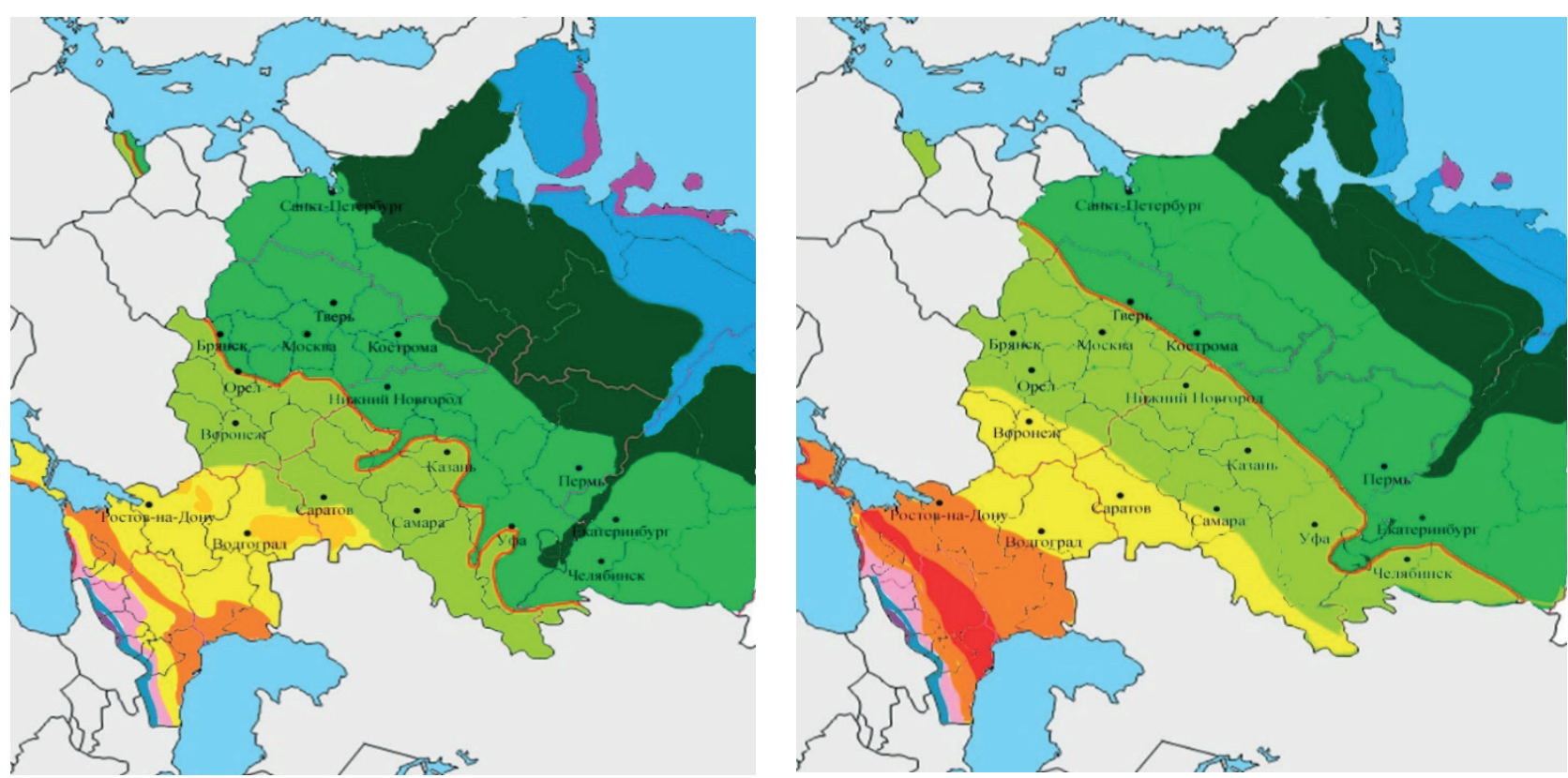

a)

б)

\begin{tabular}{|c|c|c|c|}
\hline Пояс & Обозначение & $\sum \mathrm{T}_{\mathrm{akT},}{ }^{\circ} \mathrm{C}$ & ГTK \\
\hline \multirow{2}{*}{ Холодный пояс } & & менее 400 & \multirow{3}{*}{ Избыточное увлажнение $(>1,5)$} \\
\hline & & $400-1000$ & \\
\hline \multirow{5}{*}{ Умеренный пояс } & & $1000-1600$ & \\
\hline & & $1600-2200$ & \multirow{2}{*}{$\begin{array}{c}\text { Достаточное увлажнение }(1,0-1,5), \\
\text { вероятность засух - } 25 \%\end{array}$} \\
\hline & & $2200-2800$ & \\
\hline & & $2800-3400$ & $\begin{array}{l}\text { Засушливый вегетационный период } \\
(0,5-1,0) \text {, вероятность засух - 25-50 \% }\end{array}$ \\
\hline & & $3400-4000$ & \multirow{2}{*}{$\begin{array}{l}\text { Сухой вегетационный период (0,3- } \\
\text { 0,5), вероятность засух - более } 70 \text { \% }\end{array}$} \\
\hline убтропический поя & & более 4000 & \\
\hline
\end{tabular}

Рис. 2 - Границы агроклиматических поясов на Европейской территории России: а) в 1964 г.; б) в настоящее время*

*Примечание. Территории агроклиматических поясов обозначены автором на основании данных [12] и карты агроклиматических поясов (1964).

тивных температур - 2000-2200․ ГТК находится в пределах оптимума или выше.

В центральный агроэкологический район были включены Смоленская, Московская, Калужская, Владимирская и Ивановская области. Средняя температура за вегетационный период здесь составляет $16,0-17,0^{\circ} \mathrm{C}$, сумма активных температур - $2200-2400^{\circ} \mathrm{C}$. ГТК за вегетацию находится в пределах нормы, таким образом обеспечиваются условия достаточного увлажнения.

Южный агроэкологический район (Брянская, Орловская, Рязанская, Тульская области) характеризуется повышенными температурами воздуха, которые в среднем за вегетацию составляют $17,0-18,0^{\circ} \mathrm{C}$. Суммы активных температур находятся в среднем на уровне $2400-2600^{\circ} \mathrm{C}$. Следует отметить, что за последние десятилетия этот показатель в некоторые годы значительно превышал средние значения и достигал в некоторых регионах $2900^{\circ} \mathrm{C}$. Наряду с повышенными температурами в этом агроэкологическом районе достаточно часто наблюдаются годы с недостаточным количеством выпавших осадков, ГТК находится в пределах $0,7-1,1^{\circ} \mathrm{C}$.

В результате сравнения одного из важнейших показателей климата - сумм активных температур было выявлено повсеместное их повышение по всей территории Европейской России и сдвиг границ агроклиматических поясов на несколько градусов к северу $[11,12,13]$.

Московский регион оказался в поясе с суммой активных температур от 2200 до $2800^{\circ} \mathrm{C}$ за вегетационный период, в то врем, как еще несколько десятилетий назад максимальная сумма активных температур в регионе достигала только $2200^{\circ} \mathrm{C}$ (рис. 2). При этом регион остался в зоне достаточного увлажнения с вероятностью засушливых периодов не более $25 \%$. Значительно продвинулся на север агроклиматический пояс с суммой активных температур за вегета- 
цию на уровне $2800-3400^{\circ} \mathrm{C}$. В этой зоне оказались южные регионы Центрального Нечерноземья, вероятность засух здесь составляет уже до 50 \%, то есть каждый второй вегетационный период.

\section{Обсуждение}

В Центральном районе Нечерноземной зоны РФ основным лимитирующим фактором для возделывания сои являются тепловые ресурсы. При этом работа по интродукции сои в этом регионе, начатая в 80-е годы прошлого столетия, в последние годы получила мощный импульс ввиду возрастающей потребности в соевом белке предприятий, работающих в сфере пищевой промышленности, а также производства кормовой базы для животноводства [14, 15]. Однако среди ученых нет единой стратегии в разработке модели сорта сои северного экотипа для региона. Большинство селекционеров отдают предпочтение в этом регионе сортам детерминантного типа роста, с минимальным ветвлением или полным отсутствием боковых побегов. Такие сорта характеризуются максимальной скороспелостью, они имеют короткий период цветения, после которого их линейный рост прекращается и начинается процесс созревания семян [16].

При этом детерминантные сорта сои имеют короткий стебель и, соответственно, ограниченное число ветвей, что приводит к снижению потенциальной продуктивности, а также к уменьшению высоты крепления нижнего боба, что в свою очередь ведет к дополнительным потерям урожая при уборке [17, 18, 19]. Часть вышеописанных проблем зачастую можно решить путем подбора оптимальных нормы высева и способа посева, которые обеспечат более высокое расположение нижнего боба [20]. В то же время на обусловленную генетически одностебельность повлиять нельзя, соответственно потенциальная урожайность семян и сбор белка с единицы площади будет ниже.

Сорта полудетерминантного и индетерминантного типа роста формируют боковые побеги, которые способны компенсировать изреженность посева, возникающую из-за пониженной всхожести по причине возможных весенних заморозков, возврата холодов, образования почвенной корки и др. Они, как правило, более позднеспелые, но и более урожайные. При этом характеризуются более высоким креплением нижних бобов, что обеспечивает минимальные потери при уборке.

Локальное изменение климата ЦРНЗ РФ привело к смещению изотермы суммы активных температур на 150-200 км в сторону высоких широт: если 40 лет назад изотерма проходила по северной части Брянской и Орловской областей, включала небольшой фрагмент Калужской области и Рязанскую область, то в настоящее время изотерма проходит по северной части Московской области, частично заходя на территорию Тверской области, включает Владимирскую область и южную часть Костромской области. Биологические минимумы температур выдерживаются на всех этапах роста и развития растений, обеспечивая устойчивое созревание сои в этом регионе в августе - начале сентября.

\section{Заключение}

1. В результате анализа агроклиматических условий в ЦРНЗ РФ за последние четыре десятилетия было выявлено локальное потепление климата на фоне его аридизации. Сумма активных температур возросла в зависимости от агроклиматического района от $1700-2200^{\circ} \mathrm{C}$ до $1950-2400^{\circ} \mathrm{C}$. Количество выпадающих осадков за вегетационный период уменьшилось в среднем на 20-40 мм - от 270-280 мм до 190-230 мм, гидротермический коэффициент увлажнения Селянинова - на 0,3-0,4 пункта - от 1,4-1,6 до 1,1-1,4 в зависимости от агроклиматического района.

2. В зависимости от агроэкологического района были выявлены достаточно существенные различия. В северном агроэкологическом районе (Тверская, Ярославская, Костромская области) сумма температур составляет 2000$2200^{\circ}$ С, ГТК - 1,4-1,7, сумма осадков - 285-295. В центральном агроэкологическом районе (Смоленская, Московская, Калужская, Владимирская, Ивановская области) сумма температур составляет 2200-2400 ${ }^{\circ} \mathrm{C}$, ГТК - 1,1-1,4, сумма осадков - 265-285. В южном агроэкологическом районе (Брянская, Орловская, Рязанская, Тульская области) сумма температур составляет 2400-2600 ${ }^{\circ} \mathrm{C}$, ГТК - 0,7-1,1, сумма осадков - 255-265.

3. Локальное изменение климата ЦРНЗ РФ привело к смещению изотермы суммы активных температур на 150-200 км в сторону высоких широт: если 40 лет назад изотерма проходила по северной части Брянской и Орловской областей, включала небольшой фрагмент Калужской области и Рязанскую область, то в настоящее время изотерма проходит по северной части Московской области, частично заходя на территорию Тверской области, включает Владимирскую область и южную часть Костромской области. Биологические минимумы температур 
выдерживаются на всех этапах роста и развития растений, обеспечивая устойчивое созревание сои в этом регионе в августе - начале сентября.

\section{Библиографический список}

1. Доклад об особенностях климата на территории Российской Федерации за 2020 год. - Москва : Росгидромет, 2021. - 104 с.

2. Михилев, А. В. Потепление климата конкурентное преимущество сельского хозяйства Российской Федерации / А. В. Михилев // Вестник Курской государственной сельскохозяйственной академии. - 2018. - № 7. - С. 70-73.

3. Нозинич, М. Влияние потепления климата на производство полевых культур / М. Нозинич, Н. Пржуль, В. Тркулья // Вестник Нижегородской государственной сельскохозяйственной академии. - 2016. - № 2(10). - С. 23-31.

4. Павлова, В. Н. Агроклиматические ресурсы и продуктивность сельского хозяйства России при реализации новых климатических сценариев в XXI веке / В. Н. Павлова // Труды главной геофизической обсерватории. - 2013. - № 569. - С. 20-37.

5. Changing yields in the central United States under climate and technological change/E. Burchfield, N. Matthews-Pennanen, J. Schoof, C. Lant // Climatic Change. - 2020. - Vol. 159, № 3. - P. 329-346.

6. Mistry, M. N. Simulated vs. Empirical weather responsiveness of crop yields: US evidence and implications for the agricultural impacts of climate change / M. N. Mistry, E. De Cian, I. Sue Wing // Environmental Research Letters. - 2017. - Vol.12, № 7. - P. 075007.

7. Головина, Е. В. Влияние погодных условий на водный режим, пигментный комплекс и продуктивность сои / Е. В. Головина, В. Н. Зайцев // Зернобобовые и крупяные культуры. - 2016. - № 2(18). - С. 111-116.

8. Степанов, А. С. Влияние климатических характеристик и значений вегетационного индекca NDVI на урожайность сои (на примере районов Приморского края) / А. С. Степанов, Т. А. Асеева, К. Н. Дубровин // Аграрный вестник Урала. - 2020. № 1(192). - С. 10-19.

9. Омельянюк, Л. В. Продуктивность скороспелых сортов и линий сои в зависимости от изменяющихся условий произрастания / Л. В. Омельянюк, А. Х. Танакулов, А. М. Асанов // Омский научный вестник. - 2012. - № 1(108). - С. 195-198.

10. Специализированные массивы для климатических исследований: Информация ВНИИГМИ-МЦД. - URL: http:// aisori.meteo.ru/ ClimateR.

11. Золотокрылин, А. Н. Динамика засух в
Европейской России в ситуации глобального потепления / А. Н. Золотокрылин, В.В.Виноградова, Е. А. Черенкова // Проблемы экологического мониторинга и моделирования экосистем. - 2007. - Т. 21. - С. 160-182.

12. Мингалев, Д. Э. Изменение климата в России (1985-2016) на примере сравнения старой и новой карт агроклиматических поясов / Д. Э. Мингалев // Евразийский союз ученых. - 2017. - № 9-3 (42). - C. 5-9.

13. Суховеева, О. Э. Изменения климатических условий и агроклиматических ресурсов в Центральном районе Нечерноземной зоны / О. Э. Суховеева // Вестник Воронежского государственного университета. Серия: География. Геоэкология. - 2016. - № 4. - С. 41-49.

14. Зайцев, Н. И. Влияние погодных факторов на продуктивность перспективных линий сои в зоне неустойчивого увлажнения / Н. И. Зайцев, В. Ю. Ревенко, Э. Г. Устарханова // Масличные культуры. - 2020. - № 2(182). - С. 62-69.

15. Гатаулина, Г. Г. Рост и развитие раннеспелых сортов сои при разных сроках посева в Московской области / Г. Г. Гатаулина, М.Е.Белышкина // Кормопроизводство. - 2012. - № 3. - С. 26-28.

16. Белышкина, М. Е. Урожайность и элементы структуры урожая ультраскороспелого сорта сои Касатка при разных способах посева и густоте стояния растений / М. Е. Белышкина, Г. Г. Гатаулина // Известия Тимирязевской сельскохозяйственной академии. - 2010. - № 6. - С. 51-54.

17. Научно-практические основы возделывания сортов сои северного экотипа в Нечерноземной зоне России : учебное пособие / Т. П. Кобозева, В. А. Шевченко, У. А. Делаев, В. Т. Синеговская, Н. П. Попова. - Москва : ВНИИГиМ им. А.Н. Костякова, 2016. - 244 с.

18. Гуреева, Е. В. Влияние метеорологических условий на хозяйственно ценные признаки сои / Е. В. Гуреева // Вестник российской сельскохозяйственной науки. - 2021. - № 1. - С. 28-31.

19. Фадеев, А. А. Слагающие величины продуктивности сои и параметры модели нового сорта северного экотипа для условий $56^{\circ}$ с.ш. / А. А. Фадеев // Аграрная наука Евро-СевероВостока. - 2012. - № 3(28). - С. 13-17.

20. Влияние норм высева и способов посева на урожайность и качество семян раннеспелых сортов и форм сои северного экотипа / М. Е. Белышкина, Т. П. Кобозева, В. А. Шевченко, У. А. Делаев // Известия Тимирязевской сельскохозяйственной академии. - 2018. - Вып. 4. - С. 182-190. 


\title{
AGROCLIMATIC CHARACTERISTICS OF REGIONS OF THE NON-BLACK SOIL ZONE OF THE RUSSIAN FEDERATION AND SUITABILITY ESTIMATION FOR CULTIVATION OF MODERN EARLY SOYBEAN VARIETIES
}

\author{
Dorokhov A.S., Belyshkina M.E. \\ FSBSI "Federal Scientific Agroengineering Center VIM" \\ 109428, Moscow, 1st Institutskiy dr., 5, \\ tel.: (903) 271-31-05 \\ e-mail: vimsoya@yandex.ru
}

Key words: soybean, Central Non-Black Soil Region, agroecological regions, climate warming, sum of active temperatures, hydrothermal coefficient, northern boundary of soybean cultivation.

An increase of warm period duration has been recorded in the Central Non-Black Soil region in recent years, which occurs due to a rise of the number of days with positive temperatures: the transition through $0^{\circ} \mathrm{C}$ towards an increase in temperatures occurs earlier, and towards a decrease - later than the accepted average long-term values. The aim of the research was to analyze the parameters of climate change in the Central Non-Black Soil Region and to indicate the displacement of the northern border of the acceptable distribution of soybean crops in the region. As a result of studying of agrometeorological database for a 40-year period from 1981 to 2020, the Central Economic Region of the Non-Black Soil Zone of the Russian Federation was notionally divided into 3 agroecological regions: northern, central and southern. The division was based on climatic temperature factors - the average temperature during the vegetation season and the sum of active temperatures during the growing season. Along with temperatures, the amount of precipitation and the value of HTC for the vegetation season were analyzed. Changes of agroclimatic conditions in the agroecological regions of the Central Economic Region of the Non-Black Soil Zone of the Russian Federation are currently significantly different: as for the northern agroecological region (Tver, Yaroslavl, Kostroma regions), the sum of temperatures is $2000-2200^{\circ} \mathrm{C}$, the HTC is 1.4-1.7, the amount of precipitation is 285-295. The sum of temperatures in the central agroecological region (Smolensk, Moscow, Kaluga, Vladimir, Ivanovo regions) is $2200-2400^{\circ} \mathrm{C}$, the HTC is 1.1-1.4, the amount of precipitation is 265-285. And the sum of temperatures in the southern agroecological region (Bryansk, Oryol, Ryazan, Tula regions) is $2400-2600^{\circ} \mathrm{C}$, the HTC is $0.7-1.1$, the amount of precipitation is $255-265$. In general, the local climate change in the Central Economic Region of the Non-Black Soil Zone of the Russian Federation led to a shift of the sum isotherm of active temperatures by 150-200 km towards high latitudes. Early varieties of soybeans are able to form a stable yield in the changed weather conditions of the Central Economic Region of the Non-Black Soil Zone of the Russian Federation. Biological temperature minima are maintained at all stages of growth and development, maturation occurs in August - early September.

Bibliography:

1. Report on climate peculiarities on the territory of the Russian Federation for 2020. - Moscow: Roshydromet, 2021.- $104 \mathrm{p}$.

2. Mikhilev, A. V. Climate warming - a competitive advantage of agriculture in the Russian Federation / A. V. Mikhilev // Vestnik of Kursk State Agricultural Academy. - 2018. - № 7. - P. 70-73.

3. Nozinich, M. The influence of climate warming on production of field crops / M. Nozinich, N. Przhul, V. Trkuliya // Vestnik of Nizhny Novgorod State Agricultural Academy. - 2016. - № 2 (10). - P. 23-31.

4. Pavlova, V. N. Agroclimatic resources and productivity of Russian agriculture in implementation of new climatic scenarios in the XXI century / V. N. Pavlova // Proceedings of the main geophysical observatory. - 2013. - № 569. - P. 20-37.

5. Changing yields in the central United States under climate and technological change / E. Burchfield, N. Matthews-Pennanen, J. Schoof, C. Lant // Climatic Change. - 2020. - Vol. 159, № 3. - P. 329-346.

6. Mistry, M. N. Simulated vs. Empirical weather responsiveness of crop yields: US evidence and implications for the agricultural impacts of climate change / M. N. Mistry, E. De Cian, I. Sue Wing // Environmental Research Letters. - 2017. - Vol.12, № 7. - P. 075007.

7. Golovina, E. V. Influence of weather conditions on water regime, pigment complex and productivity of soybeans / E. V. Golovina, V. N. Zaitsev // Grain legumes and cereals. - 2016. - № 2 (18). - P. 111-116.

8. Stepanov, A.S. Influence of climatic characteristics and vegetation index NDVI values on yield of soybeans (on the example of Primorsky Krai regions) / A.S. Stepanov, T.A. Aseeva, K.N. Dubrovin // Agrarian Vestnik of the Urals. - 2020. - № 1 (192). - P. 10-19.

9. Omeliyanyuk, L.V. Productivity of early varieties and lines of soybeans depending on the changing growing conditions / L.V. Omeliyanyuk, A. Kh. Tanakulov, A.M. Asanov // Omsk Scientific Vestnik. - 2012. - № 1 (108). - P. 195-198.

10. Special arrays for climate research: Information from All-Russian Scientific Research Institute of Hydrometeorological Information - World Data Center. - URL: http://aisori.meteo.ru/ClimateR.

11. Zolotokrylin, A. N. Dynamics of droughts in European Russia in a global warming situation / A. N. Zolotokrylin, V. V. Vinogradova, E. A. Cherenkova // Problems of ecological monitoring and modeling of ecosystems. - 2007. - V. 21. - P. 160-182.

12. Mingalev, D. E. Climate change in Russia (1985-2016) on the example of comparing old and new maps of agroclimatic zones / D. E. Mingalev // Eurasian Union of Scientists. - 2017. - № 9-3 (42). - P. 5-9.

13. Sukhoveeva, O.E. Changes of climatic conditions and agroclimatic resources in the Central region of the Non-Black Soil zone / O.E. Sukhoveeva // Vestnik of Voronezh State University. Series: Geography. Geoecology. - 2016. - № 4. - P. 41-49.

14. Zaitsev, N.I. The influence of weather factors on productivity of high-potential soybean lines in the zone of unstable moisture / N.I. Zaitsev, V. Yu. Revenko, E.G. Ustarkhanova // Oil crops. - 2020. - № 2 (182). - P. 62-69.

15. Gataulina, G.G. Growth and development of early soybean varieties at different sowing dates in Moscow region / G.G. Gataulina, M.E. Belyshkina // Feed production. - 2012. - № 3. - P. 26-28.

16. Belyshkina, M.E. Productivity and elements of the harvest structure of ultra-early Kasatka soybean variety in case of different sowing methods and plant density /M.E. Belyshkina, G.G. Gataulina // Izvestia of Timiryazev Agricultural Academy. - 2010. - № 6. - P. 51-54.

17. Scientific and practical bases of cultivation of northern ecotype soybean varieties in the Non-Black Soil zone of Russia: a textbook / T.P. Kobozeva, V. A. Shevchenko, U. A. Delaev, V. T. Sinegovskaya, N. P. Popova. - Moscow: All-Russian Research Institute of Hydraulic Engineering and Melioration named after A. N. Kostyakov, 2016.- 244 p.

18. Gureeva, E. V. Influence of meteorological conditions on economically valuable traits of soybeans / E. V. Gureeva // Vestnik of Russian agricultural science. - 2021. - № 1. - P. 28-31.

19. Fadeev, A.A. Components of soybean productivity and parameters of a new variety model of the northern ecotype for conditions of $56^{\circ} \mathrm{N}$. / A. A. Fadeev // Agricultural science of the Euro-North-East. - 2012. - № 3 (28). - P. 13-17.

20. Influence of seeding amount and sowing methods on yield and quality of seeds of early varieties and forms of soybeans of the northern ecotype / M.E. Belyshkina, T. P. Kobozeva, V. A. Shevchenko, U. A. Delaev // Izvestiya of Timiryazev Agricultural Academy. - 2018. - Issue. 4. - P. 182-190. 